\title{
Relationship of Science Process Skills and Critical Thinking of Students in Physics Subject
}

\author{
Wawan Kurniawan ${ }^{1}$, Haerul Pathoni ${ }^{1}$, Louisiana Muliawati ${ }^{2}$, Dwi Agus Kurniawan ${ }^{1, *}$, \\ Dinda Desma Romadona ${ }^{1}$, Aziza Putri Ningsi ${ }^{1}$, Retno Wulan Dari ${ }^{1}$ \\ ${ }^{1}$ Department of Physics Education, Faculty of Teaching and Education, Universitas Jambi, Indonesia \\ ${ }^{2}$ Faculty of Tadris and Tarbiyah, UIN Sulthan Thaha Saifuddin Jambi, Indonesia
}

Received June 23, 2020; Revised August 24, 2020; Accepted September 11, 2020

\begin{abstract}
Cite This Paper in the following Citation Styles
(a): [1] Wawan Kurniawan, Haerul Pathoni, Louisiana Muliawati, Dwi Agus Kurniawan, Dinda Desma Romadona, Aziza Putri Ningsi, Retno Wulan Dari, "Relationship of Science Process Skills and Critical Thinking of Students in Physics Subject," Universal Journal of Educational Research, Vol. 8, No. 11, pp. 5581 - 5588, 2020. DOI: 10.13189/ujer.2020.081162.
\end{abstract}

(b): Wawan Kurniawan, Haerul Pathoni, Louisiana Muliawati, Dwi Agus Kurniawan, Dinda Desma Romadona, Aziza Putri Ningsi, Retno Wulan Dari (2020). Relationship of Science Process Skills and Critical Thinking of Students in Physics Subject. Universal Journal of Educational Research, 8(11), 5581 - 5588. DOI: 10.13189/ujer.2020.081162.

Copyright $\bigcirc 2020$ by authors, all rights reserved. Authors agree that this article remains permanently open access under the terms of the Creative Commons Attribution License 4.0 International License

\begin{abstract}
The purpose of this study was to see how the relationship between the scientific process and the critical thinking skills of Al-Falah Islamic High School Jambi students on the pure harmonic motion material. This research method is a mixed methods research with the research design being the embedded design. The subjects of this study were 100 students of class XII MIPA at Al-Falah Islamic High School Jambi. The sampling technique used was purposive sampling. The data collection instruments were the science process skills observation sheet, the critical thinking ability test, and the interview sheet, which were analyzed using descriptive statistics and inferential statistics. The science process skills observed in this study are integrated science process skills with indicators of planning experiments, obtaining and processing data, and describing the relationship between variables. Meanwhile, the sign of critical thinking ability is to provide further explanation and formulate strategies and tactics. The results of the analyzed data showed that the sig value was $0.000<0.05$, so it could be concluded that there was a relationship between the science process skills and the students' critical thinking skills with a Pearson correlation value of 0.848 and it was positive. This research shows that the students of class XII MIPA at Al-Falah Islamic High School Jambi have excellent science process skills and good enough critical thinking skills.
\end{abstract}

Keywords Physics, Science Process Skills, Critical Thinking

\section{Introduction}

Education has a very strategic role in improving the quality and potential of human resources. School intends to help students empower their potential or develop their human potential [1] [2]. According to [3], education is a conscious and planned effort to create an atmosphere of learning and learning process so that students actively develop their potential. States that school has a critical role in shaping and preparing human resources to compete in the development of Science and Technology [4].

Education in Indonesia is well integrated and needs further development [5]. Education is a process to influence students to adapt to their environment [6]. Education is an activity that aims to prepare students to become people who have a positive contribution to society [7]. In education in Indonesia itself, there are several levels, one of which is the high school level [8]. High School is a level of knowledge that must be taken by students before continuing to higher education. In high school, students will study natural sciences, one of which is physics. 
Physics is one of the compulsory subjects for students at the Senior High School level. Physics has become one of the questions related to scientific concepts [9]. Physics learning that is based on ideas requires high understanding. Physics learning is a science that discusses the symptoms and properties of objects in nature [10]. Physics is part of science [11]. States weaker natural science closer to science learning and thinking scientists to physics please rephrase this sentence [12].

The purpose of science education is to educate students who can have skills and be able to think critically [13]. In science, learning students are required to have a scientific attitude. With a scientific approach, students will be skilled and think critically in solving problems by the main objectives of the education system [14]. The developed scientific attitude includes honesty, purpose, open, resilient, critical, and can work together with others. This is in line with Rinsiyah (2016) opinion that physics develops aspects of scientific attitudes [15]. Experimental approaches of students can be acquired through practical activities. According to [16], the implementation of a physics practicum is critical to supporting learning and emphasizing aspects of the process. One of the physics materials that can be done with practicum-based education is simple harmonic motion. Simple Harmonic Motion is regularly moving back and forth through the point of balance with the number of vibrations of the object in every second is always the same or constant. Any motion that repeatedly occurs in the same time interval is called a periodic motion [17]. To find out and maximize the concept of simple harmonic motion in students, practicum activities are needed, namely in the form of experiments on a simple pendulum so that students gain direct experience in making discoveries based on existing concepts and facts. Practicum is carried out so that students can connect theory with relevant experiments following everyday life so that it can be understood [10] [18] [19].

Practical activities will shape science process skills and critical thinking skills in students. The Science process skills is a complex ability device commonly used by scientists to conduct scientific investigations into a series of the learning process [20] [21]. Science process skills are thinking skills that are used to create knowledge, solve problems, and formulate results [22]. Science process skills are tools used by students to investigate the world around them and to develop science concepts [23] [24]. Science process skills are students' ability to apply scientific methods in understanding, developing \& discovering science [25]. Science process skills are critical because they help science learning and the generation of scientific knowledge [26] [27]. So the definition of science process skills implies that every student who passes through the formal education system must know science process skills.

Science process skills fall into two types: necessary science process and integrated science process skills [28] [29]. Necessary science process skills include observation, classification, measurement, prediction, communication, and inferring [30] [31] [32]. Whereas integrated science process skills include Variable Identification, Arranging data tables, Making graphs, Obtaining and processing data, Describing relationships between variables, Identifying variables operationally, Making hypotheses, Experimental analysis, Designing investigations, and Conducting experiments [33] [34] [35]. Integrated Science Process Skills are skills for solving problems or conducting science experiments [36]. From the above understanding shows that with process skills, students try to find and develop cognitive and psychomotor abilities. So that science process skills can support students in developing critical thinking skills.

Critical thinking is part of high order thinking [37] [38]. Thinking skills are developed through active learning activities, namely, critical thinking skills. Critical thinking is reflective in-depth in decision making and problem-solving to analyze situations, evaluate arguments, and draw appropriate conclusions [39]. Critical thinking is an activity of thinking carried out by operating the intellectual potential to investigate, make judgments, correct decisions, and implement them correctly [40] [41]. Therefore students must be able to think critically after the demands of education at this time. The purpose of critical thinking is to broaden students' views as support of their ideals. Critical thinkers can search for, understand, and evaluate statements that are logically and rationally relevant during problem-solving or decision making [42] [43]. So the ability to think critically is a method of learning or the right way that we must instill in the process of learning physics.

Critical thinking means being able to think logically and profoundly and be able to systematically seek and evaluate as a result of learning [44] [45]. The purpose of critical thinking has a broader view of critical thinking, which is almost the same as the ideal ideality [46]. Critical thinking includes the necessary intellectual skills, but these skills can be used to serve two purposes: self-centered or other thoughts [47]. Critical thinking is a process that depends, develops a variety of skills and qualities of self [48]. Critical thinking involves more than just possessing and applying specific skills in terms of logic [49]. Critical thinking as a process of assessing and analyzing one's thoughts to improve them [50]. The ability to think critically is the ability to practice, evaluate, carefully [51]. Five indicators of critical thinking ability are often used, provide simple explanations, build necessary skills, make conclusions, make further explanations, and set strategies and tactics [52].

Based on the literature review, critical thinking can develop students' science process skills, so research was conducted on the relationship between science process skills and critical thinking skills of students at Al-Falah 
Islamic High School Jambi on pure harmonic motion material. Based on the description above, the researcher will analyze the relationship between science process skills and students' critical thinking skills in learning Physics at Al-Falah Islamic High School Jambi. The purpose of this study was to see the relationship between science process skills and critical thinking skills of students at Al-Falah Islamic High School Jambi in simple harmonic motion.

\section{Materials and Methods}

This research method uses a mixed research method. A mixed research method is a research method that combines quantitative and qualitative methods to be used together in research activity, to obtain more comprehensive, valid, reliable, and objective data [53]. The research design used in this study is the embedded design, a mixed research design that collects quantitative and qualitative data together, where one of the data supports other data [54].

The research was conducted in SMA Islam Al-Falah Jambi, with this research subject is 100 class XII students of Mathematics. To determine the research sample, researchers used a purposive sampling technique. Mechanical purposive sampling is a sampling technique used by researchers if the researchers have specific criteria in taking samples [55]. The instruments used in this study were observation sheets of science process skills, tests of critical thinking skills, and interview sheets. The science process skills observed in this study are integrated science process skills with indicators planning experiments, obtaining and processing data, and describing the relationships between variables. In contrast, the ability to think at a higher level is focused on critical thinking skills, with indicators of critical thinking skills that provide further explanation and develop strategies and tactics.
Data analysis was performed on quantitative and qualitative data. This quantitative data analysis technique uses statistical analysis, namely, descriptive statistical analysis and inferential statistical analysis. The descriptive statistical analysis describes data from the average value, maximum and minimum values, standard deviations, and range so that it can quickly get an idea of the characteristics of objects from the data. While inferential analysis for testing hypotheses, namely using the Pearson product-moment correlation test with the SPSS 25 program. Also, interviews were conducted to obtain qualitative data to strengthen quantitative data. Discussions were aimed at teachers and students by asking questions about science process skills and critical thinking skills.

\section{Results}

\subsection{Integrated Science Process Skills}

The following are the results of the descriptive statistical analysis of integrated science process skills in the planning and experimentation using the SPSS 25 program, which can be seen in Table 1 below.

Based on Table 1, there are four categories of integrated science process skills in the indicators of planning an experiment. In contrast, the very not right and not suitable types are included in the not good category. While good and very good are included in both classes. Based on Table 1, there were 37 students out of 100 students in the wrong type, with a $37 \%$ percentage. Students categorized as useful have a higher rate of $63 \%$, with a total of 63 out of 100 students. Also obtained is a standard deviation of 3.27 , a mean value of 11.72 , a maximum value of 16 , and a minimum value of 4 .

Table 1. Results of Indicators for Experimental Planning

\begin{tabular}{|c|c|c|c|c|c|c|c|c|}
\hline \multicolumn{3}{|c|}{ Characteristics } & \multirow{2}{*}{ Mean } & \multirow{2}{*}{ Std. Deviation } & \multirow{2}{*}{ Max } & \multirow{2}{*}{ Min } & \multirow{2}{*}{ Range } & \multirow{2}{*}{$\%$} \\
\hline Interval & Category & Total & & & & & & \\
\hline $4.00-7.00$ & Very Not Good & 11 & \multirow{4}{*}{11.72} & \multirow{4}{*}{3.27} & \multirow{4}{*}{16.00} & \multirow{4}{*}{4.00} & \multirow{4}{*}{12.00} & 11 \\
\hline $7.01-10.00$ & Not Good & 26 & & & & & & 26 \\
\hline $10.01-13.00$ & Good & 26 & & & & & & 26 \\
\hline $13.01-16.00$ & Very Good & 37 & & & & & & 37 \\
\hline \multicolumn{2}{|c|}{ Total } & 100 & & & & & & 100 \\
\hline
\end{tabular}

Table 2. Results from Indicators of Gaining and Processing Data

\begin{tabular}{|c|c|c|c|c|c|c|c|c|}
\hline \multicolumn{3}{|c|}{ Characteristics } & \multirow{2}{*}{ Mean } & \multirow{2}{*}{ Std. Deviation } & \multirow{2}{*}{ Max } & \multirow{2}{*}{ Min } & \multirow{2}{*}{ Range } & \multirow{2}{*}{$\%$} \\
\hline Interval & Category & Total & & & & & & \\
\hline $4.00-7.00$ & Very Not Good & 14 & \multirow{4}{*}{11.38} & \multirow{4}{*}{3.44} & \multirow{4}{*}{16.00} & \multirow{4}{*}{4.00} & \multirow{4}{*}{12.00} & 14 \\
\hline $7.01-10.00$ & Not Good & 27 & & & & & & 27 \\
\hline $10.01-13.00$ & Good & 24 & & & & & & 24 \\
\hline $13.01-16.00$ & Very Good & 35 & & & & & & 35 \\
\hline \multicolumn{2}{|c|}{ Total } & 100 & & & & & & 100 \\
\hline
\end{tabular}


Based on Table 2. There are four categories of integrated science process skills in the indicators of obtaining and processing data. In contrast, the types that are not very good and not good are included in the wrong category. While good and very good are included in both classes. Based on Table 2, there were 41 students out of 100 students who were classified as not useful, with a $41 \%$ percentage. Students who are categorized as useful have a higher rate of $59 \%$, with a total of 59 out of 100 students. Also obtained is a standard deviation of 3.44 , a mean value of 11.38 , a maximum value of 16 , and a minimum value of 4.

Based on Table 3. There are four categories of integrated science process skills in the indicator describing the relationship between variables. In contrast, the classes are not very good and not good included in the wrong category. While good and very good are included in both types. Based on Table 3, there are 50 students out of 100 students in the lousy class, with a percentage of $50 \%$. Students who are categorized as useful have a higher rate of $50 \%$, with a total of 59 out of 100 students. A standard deviation of 5.61 is also obtained, a mean value of 14.44 is a maximum value of 24 and a minimum value of 6 .

\subsection{Critical Thinking Skills}

The results of the descriptive statistical data analysis of Critical Thinking Skills using the SPSS 25 application are shown in Table 4.

Based on Table 4. There are four categories of critical thinking skills in the indicator member further explanation. In contrast, the class that are not very good and not good are included in the group of not excellent. While good and very good are included in both categories. Based on Table 4, there are 54 students out of 100 students in the lousy class, with a percentage of $54 \%$. Students who are categorized as useful have a higher rate of $46 \%$, with a total of 46 out of 100 students. A standard deviation of 2.39 is also obtained, a mean value of 5.03 is a maximum of 8 and a minimum amount of 2 .

Table 3. Results of the Indicator Describe the Relationship between Variables

\begin{tabular}{|c|c|c|c|c|c|c|c|c|}
\hline \multicolumn{3}{|c|}{ Characteristics } & \multirow{2}{*}{ Mean } & \multirow{2}{*}{ Std. Deviation } & \multirow{2}{*}{ Max } & \multirow{2}{*}{ Min } & \multirow{2}{*}{ Range } & \multirow{2}{*}{$\%$} \\
\hline Interval & Category & Total & & & & & & \\
\hline $6.00-10.50$ & Very Not Good & 33 & \multirow{4}{*}{14.44} & \multirow{4}{*}{5.61} & \multirow{4}{*}{24.00} & \multirow{4}{*}{6.00} & \multirow{4}{*}{18.00} & 33 \\
\hline $10.51-15.00$ & Not Good & 17 & & & & & & 17 \\
\hline $15.01-19.50$ & Good & 23 & & & & & & 23 \\
\hline $19.51-24.00$ & Very Good & 27 & & & & & & 27 \\
\hline \multicolumn{2}{|c|}{ Total } & 100 & & & & & & 100 \\
\hline
\end{tabular}

Table 4. Results of Indicators Provide Further Explanation

\begin{tabular}{|c|c|c|c|c|c|c|c|c|}
\hline \multicolumn{3}{|c|}{ Characteristics } & \multirow{2}{*}{ Mean } & \multirow{2}{*}{ Std. Deviation } & \multirow{2}{*}{ Max } & \multirow{2}{*}{ Min } & \multirow{2}{*}{ Range } & \multirow{2}{*}{$\%$} \\
\hline Interval & Category & Total & & & & & & \\
\hline $2.00-3.50$ & Very Not Good & 34 & \multirow{4}{*}{5.03} & \multirow{4}{*}{2.39} & \multirow{4}{*}{8.00} & \multirow{4}{*}{2.00} & \multirow{4}{*}{6.00} & 34 \\
\hline $3.51-5.00$ & Not Good & 20 & & & & & & 20 \\
\hline $5.01-6.50$ & Good & 10 & & & & & & 10 \\
\hline $6.51-8.00$ & Very Good & 36 & & & & & & 36 \\
\hline \multicolumn{2}{|c|}{ Total } & 100 & & & & & & 100 \\
\hline
\end{tabular}

Table 5. Results of Indicators Developing Strategies and Tactics

\begin{tabular}{|c|c|c|c|c|c|c|c|c|}
\hline \multicolumn{3}{|c|}{ Characteristics } & \multirow{2}{*}{ Mean } & \multirow{2}{*}{ Std. Deviation } & \multirow{2}{*}{$\operatorname{Max}$} & \multirow{2}{*}{ Min } & \multirow{2}{*}{ Range } & \multirow{2}{*}{$\%$} \\
\hline Interval & Category & Total & & & & & & \\
\hline $1.00-1.75$ & Very Not Good & 21 & \multirow{4}{*}{2.66} & \multirow{4}{*}{1.10} & \multirow{4}{*}{4.00} & \multirow{4}{*}{1.00} & \multirow{4}{*}{3.00} & 21 \\
\hline $1.76-2.50$ & Not Good & 20 & & & & & & 20 \\
\hline $2.51-3.25$ & Good & 31 & & & & & & 31 \\
\hline $3.26-4.00$ & Very Good & 28 & & & & & & 28 \\
\hline \multicolumn{2}{|c|}{ Total } & 100 & & & & & & 100 \\
\hline
\end{tabular}


Based on Table 5, there are four categories of critical thinking skills in the indicators compiling strategies and tactics. In contrast, the classes that are not very good and not good are included in the group of not excellent. While good and very good are included in both categories. Based on Table 5, there were 41 students out of 100 students who were classified as not useful, with a percentage of $41 \%$. Students who are categorized as useful have a higher rate of $59 \%$, with a total of 59 out of 100 students. A standard deviation of 1.10 is also obtained, a mean value of 2.66 is a maximum of 4 and a minimum amount of 1 .

The data are then analyzed to determine the relationship between two variables, namely, the relationship between integrated science process skills and the critical thinking abilities of students using the Pearson product-moment correlation test.

Table 5. Outcomes of the Relationship between Science Process Skills and Critical Thinking Skills

\begin{tabular}{|c|c|c|c|c|c|}
\hline \multirow{2}{*}{ Variable } & \multirow{2}{*}{ Mean } & \multicolumn{2}{|c|}{$\begin{array}{c}\text { Science Process } \\
\text { Skills }\end{array}$} & \multicolumn{2}{c|}{\begin{tabular}{c}
\multicolumn{2}{c|}{ Sritical Thinking } \\
\cline { 3 - 6 }
\end{tabular}} \\
\cline { 3 - 6 } & & $\mathbf{r}$ & $\begin{array}{c}\text { Sig. } \\
\text { (2-tailed) }\end{array}$ & $\mathbf{r}$ & $\begin{array}{c}\text { Sig. } \\
\text { (2-tailed) }\end{array}$ \\
\hline SPS & 64.14 & & 1 & .848 & .000 \\
\hline CTS & 66.95 & .848 & .000 & & 1 \\
\hline
\end{tabular}

From table 5 , obtain sig value $0,000<0.05$. It can be concluded that there is a relationship between science process skills with students' critical thinking skills with a person correlation value of 0.848 and positive value. If the value of sig. $<0.05$, then there is a relationship [56].

\section{Discussion}

The data that have been analyzed produce that in the integrated science process skills on pure harmonic motion material on the indicators of planning an experiment, students have the most significant percentage of $63 \%$, which is in a proper category. This means that on this indicator, students can determine the tools and materials for the experiment. On the symbol of obtaining and processing, students have the most significant percentage of $59 \%$, which is in a proper category. In this indicator, students are also able to display data in the form of experimental table results. The index describing the relationship between student variables has the most significant percentage of $50 \%$, which is in the proper category. This means that on this indicator, students can criticize the use of equations in experiments. From this explanation, it appears that students have mastered integrated science process skills. Students who master integrated process skills also master necessary science process skills.

Observation skills are the essential skills that can support the subsequent mastery of skills, namely, integration process skills. When students are skilled in necessary science process skills, their integrated science process skills will also be useful. Through practicum activities that lead to student activity in discovering new things, it can improve students' science process skills. However, the problem is that learning is currently only centered on the teacher. This is in line with the interviews that have been conducted.

Researchers also conducted interviews with students and teachers to see students' science process skills. From the results of the meeting, it can be seen that through practicum activities, it can be seen that the science process skills of Al-Falah Islamic High School Jambi are classified as useful. In general, teaching and learning activities occur during practicum activities, so that students can explore science process skills and students can understand concepts; students do not just memorize formulas without paying attention to understanding the idea or understanding the physical meaning of the method correctly. Science process skills and critical thinking skills are closely related, because students who do not have science process skills will not have critical thinking.

Based on the study results, it was found that the Al-Falah Islamic High School students in Jambi were in the critical category. The increase in students 'critical thinking skills is due to learning that applies the 2013 Curriculum, where learning is centered on students so that it can train students' critical thinking skills. The high ability of students to think critically is because students are accustomed to getting questions with cognitive level C4-C6 on the simple harmonic motion. This is in line with the results of interviews conducted by researchers with teachers and students that students have given optimal responses to problems raised by the teacher, students have been able to describe the conditions in the issue being discussed, and students have an intense curiosity so that the ability students have high critical thinking.

From the results of the Pearson correlation analysis that has been done, it is found that there is a relationship between science process skills and students' critical thinking abilities. Students who have high science process skills will tend to have high analytical thinking abilities. This happens because the indicators of science process skills already contain signs of critical thinking skills. If students master science process skills, students also have critical thinking. So that science process skills have a strong relationship with critical thinking, if students have low science process skills, then their critical thinking skills are also little.

The importance of science process skills for students is that students experience meaningful learning and be actively involved in discovering concepts from phenomena in the environment. Meaningful learning is learning that engages students directly, and knowledge will be easy to remember. Students who have excellent science process skills can master the next skill. Students who have science process skills can think critically. Critical thinking skills are needed to understand physics 
concepts well.

\section{Conclusions}

Science process skills can be related to developing students' critical thinking skills. Students' necessary science process skills are categorized as useful and have analytical thinking skills, which are also classified as useful. So there is a significant relationship between science process skills and high-level thinking skills of students with a relationship value of 0.848 and positive value. This study shows that the students of the XII MIPA grade at Al-Falah Islamic High School have excellent science process skills, as well as critical thinking skills that are also quite good. Suggestions from researchers are that teachers and schools to improve the science process skills and higher-order thinking abilities possessed by students because these two things support student success.

\section{Acknowledgments}

The researcher would like to thank the headmaster and physics teacher at Al-Falah Jambi senior high school who agreed to be the sample in this study, and everyone involved we thank you for that.

\section{REFERENCES}

[1] Grace, A. Neolaka. Landasan Pendidikan, Kencana, Depok, 2017.

[2] S. Syahrial, A. Asrial, D. A. Kurniawan, P. Nugroho, R. Septiasari, R. A. Pratama, R. Perdana. Increased Behavior of Students' Attitudes to Cultural Values Using the Inquiry Learning Model Assisted by Ethnoconstructivism, Journal of Educational Science and Technology, Vol.5, No.2, $166-175,2019$.

[3] S. Chomaidi. Pendidikan Dan Pengajaran Strategi Pembelajaran Sekolah, PT. Grasindo, 2018.

[4] E. Safitri, K. Kosim, A. Harjono. Pengaruh Model Pembelajaran Predict Observe Explain (POE) Terhadap Hasil Belajar IPA Fisika Siswa SMP Negeri 1 Lembar Tahun Ajaran 2015/2016, Jurnal Pendidikan Fisika dan Teknologi, Vol.5, No.2, 197-204, 2019.

[5] A. Astalini, D. A. Kurniawan, R. Perdana, D. Kurniasari. Identification Of Student Attitudes Toward Physics Learning At Batanghari District High School, The Educational Review, Vol.2, No.9, 475-484. 2018.

[6] S. Syahrial, A. Asrial, D. A. Kurniawan, F. Chan, R. A. Pratama, P. Nugrogo, R. Septiasari. The Impact of Etnocontructivism in Social Affairs on Pedagogic Competencies, International Journal Of Evaluation And Research In Education, Vol.8, No.3, 409-416, 2019.

[7] D. A. Kurniawan, A. Astalini, D. K. Sari. An evaluation analysis of students' attitudes towards physics learning at senior high school, Jurnal Penelitian dan Evaluasi Pendidikan, Vol.23, No.1, 26-35, 2019.

[8] D. A. Kurniawan, R. Perdana, D. Kurniasari, D. Identification of student attitudes toward physics learning at Batanghari District high school, The Educational Review, USA, Vol.2, No.9, 475-484, 2018.

[9] D. A., Kurniawan, L. R. Sholihah, R. Perdana. Characteristics of Students'attitude to Physics in Muaro Jambi High School, Humanities \& Social Sciences Reviews, Vol.7, No.2, 91-99, 2019.

[10] D. Darmaji, D. A. Kurniawan, A. Astalini, N. R. Nasih. Persepsi Mahasiswa pada Penuntun Praktikum Fisika Dasar II Berbasis Mobile LearninG, Jurnal Pendidikan: Teori, Penelitian, dan Pengembangan, Vol.4, No.4, 516-523, 2019.

[11] Maison, A. Astalini., D. A. Kurniawan, L.R Sholihah. Deskripsi Sikap Siswa SMA Negeri Pada Mata Pelajaran Fisika, Jurnal EDUSAINS, Vol.10, No.1, 160-167, 2018.

[12] A. Astalini, D. A. Kurniawan. Pengembangan instrumen sikap siswa sekolah menengah pertama terhadap mata pelajaran IPA, Jurnal Pendidikan Sains, Vol.7, No.1, 1-7, 2019.

[13] H. Aktamış, N. Yenice. Determination of the science process skills and critical thinking skill levels, Procedia-Social and Behavioral Sciences, Vol.2, No.2, 3282-3288, 2010.

[14] R. Supardi, E. Istiyono, W. Setialaksana, W. Developing Scientific Attitudes Instrument of Students in Chemistry, Journal of Physics: Conference Series, Vol.1233, No.1, $012025,2019$.

[15] I. Rinsiyah. Pengembangan modul fisika berbasis CTL untuk meningkatkan KPS dan sikap ilmiah siswa Madrasah Aliyah, Jurnal Pendidikan Matematika dan Sains, Vol.4, No.2, 152-162, 2016.

[16] H. Sudrajad. Pengembangan perangkat percobaan konsep rotasi untuk pembelajaran fisika di sma dan universitas, Jurnal Geliga Sains (JGS): Jurnal Pendidikan Fisika (Physics Education Journal), Vol.3, No.2, 2009.

[17] P. Gowri, D. Deepika, S. Krithika. A Case Study on Simple Harmonic Motion and Its Application, International Journal of Latest Engineering And ManagementResearch, Vol.2, No.8, 51-60, 2017.

[18] M. Misbah, M. Wati, M. F. Rif'at. Pengembangan Petunjuk Praktikum Fisika Dasar I Berbasis 5M Untuk Melatih Keterampilan Proses Sains dan Karakter Wasaka, Jurnal Fisika Flux: Jurnal Ilmiah Fisika FMIPA Universitas Lambung Mangkurat, Vol.15, No.1, 26-30, 2018.

[19] T. Mutiara, Ernawati, M. Miarsyah, D. Luvfiati. Ilmu Pengetahuan Alam untuk SMK dan MAK kelas X, Erlangga, Jakarta, 2006

[20] T. S. N. Manu, F. T. Nomleni. Pengaruh Metode Pembelajaran Karya Kelompok Terhadap Keterampilan Proses Sains Dengan Kovariabel Kemampuan Berpikir Kreatif Siswa Pada Mata Pelajaran Biologi, Scholaria: Jurnal Pendidikan dan Kebudayaan, Vol.8, No.2, 167-179, 2018.

[21] A. Hofstein, R. Mamlok-Naaman. The laboratory in science education: state of the art, Chemistry education research, and practice, Vol.8, No.2, 105-107, 2007. 
[22] A. Aydın. Representation of science process skills in the chemistry curricula for grades 10,11 and 12/Turkey, International Journal of Education and Practice, Vol.1, No.5, 51-63, 2013

[23] N. Gultepe. High School Science Teachers' Views on Science Process Skills, International Journal of Environmental and Science Education, Vol. 11, No.5, 779-800, 2016.

[24] H. Alfian, S. Supeno, S. H. B. Prasutowo. Identifikasi Keterampilan Proses Sains Siswa SMK Pada Pokok Bahasan Rangkaian Arus Sederhana, Jurnal Pembelajaran Fisika, Vol.7, No.3, 242-247, 2018.

[25] A. M. Hutagalung. Efek Model Pembelajaran Inquiry Training Berbasis Media Komputer Terhadap Keterampilan Proses Sains Dan Kemampuan Berpikir Kritis Siswa, Doctoral dissertation, UNIMED, 2013.

[26] B. Siachibila, A. Banda. Science process skills assessed in the examinations council of Zambia (ecz) senior secondary school chemistry-5070/3 practical examinations, Chemistry and Materials Research, Vol.10, No.5, 17-23, 2018.

[27] L. Gusdiantini, A. N. Aeni, A. K. Jayadinata. Pengembangan keterampilan proses sains siswa kelas $\mathrm{V}$ pada materi gaya gesek melalui pembelajaran kontekstual, Jurnal Pena Ilmiah, Vol.2, No.1, 651-660, 2017.

[28] N. Hırça. The influence of hands-on physics experiments on scientific Process skills according to prospective teachers' experiences1, European Journal of Physics Education, Vol.4, No.1, 6-14, 2017.

[29] D. Darmaji, D. A., Kurniawan, A. Rahayu. Development Physics Practical Guided Based on Science Process Skill Using Problem Solving. Edusains, Vol.10, No.1, 83-96, 2018 .

[30] T. E. Andini, S. Hidayat, E. N. Fadillah, T. I. Permana. Scientific process skills: Preliminary study towards senior high school student in Palembang, JPBI (Jurnal Pendidikan Biologi Indonesia), Vol.4, No.3, 243-250, 2018.

[31] R. Ergül, Y. Şımşeklı, S. Çaliş, Z. Özdılek, S. Göçmençelebı, M. Sanli. The Effects of Inquiry-Based Science Teaching on Elementary School Students' Science Process Skills and Science Attitudes, Bulgarian Journal of Science \& Education Policy, Vol.5, No.1, 2011.

[32] R. G. Raj, S. N. Devi. Science process skills and achievement in science among high school students, Scholarly Research Journal for Interdisciplinary Studies, Vol.2, No.15, 2435-2443, 2014.

[33] M. Hodosyova, J. Útla, M. Vanyová, P. Vnuková, V. Lapitková. The development of science process skills in physics education, Procedia-Social and Behavioral Sciences, Vol.186, No.2015, 982-989, 2015.

[34] F. Dönmez, N. Azizoğlu. Investigation of the student's science process skill levels in vocational schools: a case of Balıkesir, Necatibey Faculty of Education Electronic Journal of Science and Mathematics Education, Vol.4, No.2, 79-109, 2010 .

[35] V. M. Chabalengula, F. Mumba, S. Mbewe. How pre-service teachers understand and perform science process skills, Eurasia journal of mathematics, science and technology education, Vol.8, No.3, 167-176, 2012.

[36] S. Karamustafaoğlu. Improving the science process skills ability of science student teachers using I diagrams, International Journal of Physics \& Chemistry Education, Vol.3, No.1, 26-38, 2011.

[37] G. Klein. Critical thoughts about critical thinking. Theoretical Issues in Ergonomics Science, Vol.12, No.3, 210-224, 2011.

[38] W. Conklin. Higher-order thinking skills to develop 21st-century learners, Teacher Created Materials, 2011.

[39] M. Lloyd, N. Bahr. Thinking critically about critical thinking in higher education, International Journal for the Scholarship of Teaching and Learning, Vol.4, No.2, n2, 2010.

[40] H. Setiawati, A. D. Corebima. Empowering critical thinking skills of the students having different academic ability in biology learning of Senior High School through PQ4R-TPS Strategy, The International Journal of Social Sciences and Humanities Invention, Vol.4, No.5, 3521-3526, 2017.

[41] M. Ernawati, D. Muhammad, D., A. Asrial, M. Muhaimin. Identifying Creative Thinking Skills in Subject Matter Bio-Chemistry, International Journal of Evaluation and Research in Education, Vol.8, No.4, 581-589, 2019.

[42] A. Shaw, O. L. Liu, L. Gu, E. Kardonova, I. Chirikov, G. Li, Q. Su. Thinking critically about critical thinking: validating the Russian HEIghten ${ }^{\circledR}$ critical thinking assessment, Studies in Higher Education, 1-16, 2019.

[43] R. Syafitri, R. Asyhar, A. Asrial. Pengaruh Model Inquiry Training dan Berpikir Kritis Terhadap Kemampuan Berpikir Ilmiah Mahasiswa pada Mata Kuliah Kimia Dasar, Edu-Sains: Jurnal Pendidikan Matematika dan Ilmu Pengetahuan Alam, Vol.5, No.1, 2016.

[44] H. Johan. Pengaruh SSCS problem solving untuk meningkatkan keterampilan berpikir kritis mahasiswa pada pembelajaran konsep listrik dinamis, Jurnal Pendidikan Matematika \& IPA, Vol.4, No.1, 13-18, 2013.

[45] D. F. Halpern. Thought and knowledge: An introduction to critical thinking, Psychology Press, 2013.

[46] H. Siegel, C. Gables. Critical Thinking, 141-145, 2010.

[47] R. Paul, L. Elder. Critical thinking: Tools for taking charge of your professional and personal life. Pearson Education, 2013.

[48] S. Cotrell. Critical thinking skills: Developing effective analysis and argument, Palcrave Macmillan, 2005.

[49] M. S. Byrne, A. H. Johnstone. Critical thinking and science education, Studies in Higher Education, Vol.12, No.3, 37-41, 2006.

[50] J. Utriainen, M. Marttunen, E. Kallio, P. Tynjälä. University applicants' critical thinking skills: The case of the Finnish educational sciences, Scandinavian Journal of Educational Research, Vol.61, No.6, 629-649, 2017.

[51] M. Maulana. Konsep dasar matematika dan pengembangan kemampuan berpikir kritis-kreatif, UPI Sumedang Press, 2017.

[52] A. H. Aminudin, D. Rusdiana, S. Samsudin, L. Hasanah, L., 
J. Maknun. Measuring critical thinking skills of 11th-grade students on temperature and heat, Journal of Physics: Conference Series, Vol.1280, No.5, 052062, 2019.

[53] Sugiyono. Metode Penelitian Pendidikan: Pendekatan Kuantitatif, Kualitatif, Dan R\&D, Alfabeta, Bandung, 2012.

[54] J. W. Creswell. Educational Research: Planning, Conducting, and Evaluating Quantitative and qualitative Research, Pearson, USA, 2012.

[55] S. Arikunto. Manajemen Penelitian, Rineka Cipta, Jakarta, 2010.

[56] M. D. Gall, W.R. Borg, J.P. Gall. Educational research: An introduction, Pearson, USA, 2003. 